\title{
PENERAPAN MODEL PEMBELAJARAN KOOPERATIF TIPE KEPALA BERNOMOR UNTUK MENINGKATKAN AKTIVITAS DAN HASIL BELAJAR SISWA PADA MATERI KERJASAMA NEGARA-NEGARA ASIA TENGGARA DI KELAS VI SDN. NO. 013/XI SUMUR ANYIR TAHUN 2016/2017
}

\begin{abstract}
Alis Khamri ${ }^{1}$
Abstract

The research conducted is a classroom action research that aims to increase the student's activity in the class and student's learning outcome on the subjects of Civic Education by using Numbered Heads Together Model. This research was conducted in two cycles, namely cycle I and cycle II. Each cycle consists of four activities, namely planning, execution, observation, and reflection. This research involves nine students of sixth class in SDN. No. 013/XI Sumur Anyir, Sungai Penuh City, Jambi Province. Research was started from January to May in 2017. Student's learning outcome are seen from the average value in the class and student's learning completeness. The result of this research showed that Numbered Heads Together model can improve student's learning outcomes. This result is evidenced by the increase in student learning outcomes which are seen from the increase in the average value in the class and student's learning completeness before and after the action is implemented. In addition to learning outcomes, students also experience an increase also in terms of student activity in the class. The observation results indicate that all students have been listening to the teacher's explanation actively, forming a heterogeneous group, and willing to discuss answers with a group of friends. Most students have also dared to communicate the results of their group discussions and respond to other group presentations.
\end{abstract}

Keywords: civic education, conceptual understanding, elementary school students, learning outcomes, Numbered Heads Together

\section{PENDAHULUAN}

Pendidikan Kewarganegaraan (PKn) merupakan salah satu mata pelajaran wajib yang memegang peranan penting dalam pendidikan nasional. Mata pelajaran ini diajarkan mulai dari Sekolah Dasar sampai dengan Perguruan Tinggi. Mata pelajaran ini memiliki peran yang strategis dalam mempersiapkan warganegara yang cerdas, bertanggung jawab, dan berkeadaban (Kaelan, 2016). Salah satu indikator keberhasilan dalam kegiatan pembelajaran PKn adalah evaluasi hasil belajar. Apabila siswa memperoleh

\footnotetext{
${ }^{1}$ SDN. No. 013/XI Sumur Anyir, Kota Sungai Penuh, Provinsi Jambi
}

evaluasi hasil belajar yang rendah maka siswa tersebut kegiatan pembelajaran dikatakan belum berhasil. Sebaliknya, kegiatan pembelajaran dikatakan berhasil apabila siswa memperoleh evaluasi hasil belajar yang tinggi.

Keberhasilan kegiatan pembelajaran PKn yang dicapai siswa tidak terlepas dari faktor-faktor yang mempengaruhinya. Suprihatiningrum (2014) menyebutkan bahwa ada beberapa faktor yang mempengaruhi proses pembelajaran yaitu siswa, pendidik, kurikulum, sarana dan prasarana, tenaga pendidik, dan lingkungan. Suprihatiningrum (2014) menambahkan bahwa dari beberapa 
faktor tersebut, faktor yang mempunyai peranan penting dalam menentukan keberhasilan pembelajaran adalah faktor guru, seperti sikap guru dalam mengelola pembelajaran, keterampilan guru dalam mengajukan pertanyaan, pengetahuan dan keterampilan guru dalam menggunakan media pembelajaran, dan faktor pendukung lainnya.

Mata pelajaran PKn sering kurang mendapat perhatian dari semua pihak di lingkungan sekolah, baik guru maupun siswa. Mata pelajaran PKn dianggap terlalu banyak menghafal sehingga banyak siswa yang merasa jenuh dengan materi yang diajarkan pada mata pelajaran ini. Siswa merasa kurang tertarik, menganggap mudah, menjemukan, dan kurang bermanfaat. Selain faktor siswa, masalah juga ditemukan pada metode yang digunakan guru dalam mengajar, seperti penggunaan metode yang monoton dan kurang bervariasi. Akibatnya, siswa semakin jenuh.

Masalah seperti ini telah banyak terjadi di berbagai sekolah, khususnya Sekolah dasar. Afandi (2012) menemukan minat belajar siswa kelas IV di SD Negeri Panimbang 05 pada pembelajaran PKn masih rendah yaitu siswa kurang bersemangat, kurang antusias dalam belajar, dan kurang perhatian terhadap pembelajaran yang berdampak rendahnya prestasi belajar siswa. Masalah ini juga terjadi di SD Inpres Palupi (Irmayani, 2016). Prestasi belajar siswa yang rendah terjadi akibat dari keterbatasan sarana dan prasarana dan juga masalah dalam hal kemampuan profesional guru. Selain itu, masalah juga ditemukan pada siswa yakni siswa menganggap pembelajaran PKn sebagai pembelajaran yang membosankan karena model pembelajaran yang digunakan guru kurang menarik dan tidak melibatkan keaktifan siswa dalam proses pembelajaran, sehingga siswa kurang antusias mengikuti pembelajaran tersebut (Irmayani, 2016).

Suwastana (2016) juga menemukan masalah yang sama dalam proses belajar mengajar, khususnya pada mata pelajaran Pendidikan Kewarganegaraan di SDN 01 Tonggolobibi. Siswa memiliki motivasi belajar yang kurang dalam mengikuti pembelajaran, model pembelajaran yang monoton, penggunaan media yang tidak optimal, pasifnya anak didik dalam mengikuti proses pembelajaran, bahkan ada beberapa anak didik yang hanya duduk dan diam tidak pernah mempunyai ide, mereka menganggap kegiatan belajar mengajar seperti kegiatan rutinitas yaitu berangkat sekolah mengikuti kegiatan belajar mengajar, pulang dan berikutnya sama seperti itu sehingga sekolah seperti kegiatan yang membosankan. Hal ini akan mengurangi minat siswa untuk belajar PKn dan mempengaruhi prestasi belajarnya.

Keadaan tersebut juga terjadi pada siswa kelas VI SDN. No 013/XI Sumur Anyir, Kecamatan Sungai Bungkal, Kota Sungai Penuh. Berdasarkan hasil pengamatan, terlihat siswa hanya duduk diam mendengarkan guru memberikan materi. Guru mengajar secara konvensional yakni hanya dengan menggunakan metode ceramah, pembelajaran masih berpusat pada guru, guru tidak menggunakan alat peraga sebagai media pembelajaran, aktivitas siswa hanya mendengarkan penjelasan guru dan mencatat materi yang diberikan oleh guru. Siswa tidak diberi kesempatan untuk bertanya atau mengungkapkan pendapatnya. Hal tersebut pada akhirnya berdampak pada hasil belajar siswa. Hasil tes penjajakan menunjukkan bahwa nilai rata-rata yang diperoleh Sembilan orang siswa kelas VI SDN. No 013/XI Sumur Anyir 
pada mata pelajaran PKn adalah 46,67.

Nilai ini masih lebih kecil dibandingkan dengan Kriteria

Ketuntasan Minimum (KKM) mata pelajaran PKn yaitu 60. Ketuntasan belajar yang dapat dicapai siswa hanya $44,44 \%$. Hasil ini menunjukkan bahwa hanya empat siswa yang tuntas. Kondisi ini mengindikasikan bahwa hasil belajar siswa pada mata pelajaran PKn kelas VI SDN. No 013/XI Sumur Anyir masih rendah.

Berdasarkan permasalahan tersebut maka perlu adanya suatu tindakan untuk meningkatkan aktivitas dan hasil belajar siswa pada mata pelajaran PKn. Dalam hal ini, peneliti akan menggunakan model pembelajaran kooperatif tipe kepala bernomor (Numbered Heads Together). Model pembelajaran ini dipilih karena model ini memberikan kesempatan pada siswa untuk saling membagikan ide-ide dan mempertimbangkan jawaban yang paling tepat. Selain itu, teknik ini juga mendorong siswa untuk meningkatkan semangat kerjasama mereka. Model pembelajaran ini lebih mengedepankan kepada aktivitas siswa dalam mencari, mengolah, dan melaporkan informasi dari berbagai sumber yang akhirnya dipresentasikan di depan kelas. Berdasarkan uraian tersebut, peneliti melakukan penelitian tindakan kelas yang berjudul "Penerapan Model Pembelajaran Kooperatif Tipe Kepala Bernomor (Numbered Heads Together) untuk Meningkatkan Hasil Belajar Siswa pada Materi Kerjasama Negara-Negara Asia Tenggara di Kelas VI SD. No.13/XI Sumur Anyir Tahun 2016/2017". Penelitian ini bertujuan untuk meningkatkan prestasi belajar siswa kelas VI SDN. No. 013/XI Sumur Anyir pada mata pelajaran PKn dengan menerapkan model pembelajaran kooperatif tipe kepala bernomor (Numbered Heads Together).

\section{METODE PENELITIAN}

Penelitian ini merupakan penelitian tindakan kelas yang dilakukan di SDN. No. 013/XI Sumur Anyir, Kecamatan Sungai Bungkal, Kota Sungai Penuh, Provinsi Jambi. Kegiatan penelitian terdiri atas penyusunan proposal penelitian, pengumpulan data, pengolahan dan analisis data, serta penyusunan laporan. Kegiatan penelitian dilakukan sejak bulan Januari sampai dengan bulan Mei tahun 2017.

Subjek dalam penelitian ini adalah siswa kelas VI semester genap tahun pelajaran 2016/2017 di SDN. No. 013/XI Sumur Anyir, Kecamatan Sungai Bungkal, Kota Sungai Penuh, Provinsi Jambi. Jumlah subjek yang terlibat dalam penelitian ini adalah sembilan orang siswa. Objek dalam penelitian ini adalah peningkatan hasil belajar siswa kelas VI SDN. No. 013/XI Sumur Anyir pada mata pelajaran Pendidikan Kewarganegaraan.

Data yang dikumpulkan dalam penelitian tindakan kelas ini adalah data hasil belajar siswa. Data hasil belajar dikumpulkan dengan dua cara yaitu dengan evaluasi hasil belajar jenis tes dan nontes. Evaluasi hasil belajar jenis tes merupakan cara untuk melakukan proses penilaian dalam bentuk tugas atau serangkaian tugas yang harus dikerjakan siswa atau sekelompok siswa sehingga menghasilkan suatu nilai yang menggambarkan prestasi siswa. Dalam penelitian ini, tes bertujuan untuk mengukur hasil belajar siswa dengan cara guru memberikan pertanyaanpertanyaan yang harus dijawab atau perintah-perintah yang harus dijalankan oleh siswa pada mata pelajaran Pendidikan Kewarganegaraan, khususnya pada materi kerjasama negara-negara Asia Tenggara. Tes yang 
diberikan berupa tes verbal tertulis dan lisan. Setelah itu, guru memberikan penilaian terhadap hasil tes yang diperoleh siswa dengan cara menghitung nilai rata-rata kelas dan juga ketuntasan belajar. Evaluasi hasil belajar jenis nontes yang digunakan adalah pengamatan atau observasi. Observasi merupakan cara untuk menghimpun data atau bahan-bahan keterangan yang dilakukan dengan mengadakan pengamatan dan pencatatan secara sistematis terhadap fenomena-fenomena yang sedang dijadikan sasaran pengamatan. Dalam penelitian ini, observasi dilakukan untuk mengamati tingkah laku siswa selama proses pembelajaran berlangsung. Observasi dilakukan untuk mengetahui keaktifan siswa dalam melakukan skenario pembelajaran. Hasil observasi digunakan untuk mengetahui proses pembelajaran dan untuk memperbaiki kualitas pembelajaran.

Penelitian tindakan kelas ini dilaksanakan dalam dua siklus yaitu siklus I dan siklus II. Siklus I dilakukan sebanyak dua kali pertemuan dan , sedangkan siklus II dilakukan sebanyak dua kali pertemuan. Masing-masing siklus terdiri atas empat kegiatan, yaitu perencanaan, pengamatan, dan refleksi.

Data yang dikumpulkan diolah dan dianalisis untuk mengetahui efektifitas dan tingkat keberhasilan suatu tindakan dengan menggunakan uji statistik sederhana. Uji statistik yang digunakan adalah penghitungan nilai rata-rata hasil belajar siswa dengan menggunakan rumus:
Selanjutnya, nilai rata-rata dan persentase ketuntasan belajar siswa yang diperoleh dianalisis. Analisis dilakukan dengan cara membandingkan nilai rata-rata yang diperoleh siswa sebelum dan sesudah tindakan.

Indikator keberhasilan dari penelitian tindakan kelas ini adalah meningkatnya hasil belajar siswa kelas VI SDN. No. 013/XI Sumur Anyir pada mata pelajaran Pendidikan Kewarganegaraan. Peningkatan hasil belajar mengacu pada Kriteria Ketuntasan Minimum (KKM) mata pelajaran Pendidikan Kewarganegaraan yang telah ditentukan oleh sekolah di awal tahun pelajaran 2016/2017 yaitu sebesar 60.

\section{HASIL DAN PEMBAHASAN Hasil Penelitan pada Pratindakan}

Sebelum memberikan tindakan, guru mengadakan tes penjajakan terlebih dahulu pada siswa. Hasil siswa berdasarkan tes penjajakan yang telah dilakukan disajikan pada Tabel 1 . Tabel 1 menginformasikan bahwa nilai rata-rata kelas yang diperoleh sebesar 46,67. Nilai ini belum belum memenuhi KKM mata pelajaran Pendidikan Kewarga-negaraan yaitu 60. Selain itu, ketuntasan belajar siswa juga masih rendah yakni $44,44 \%$. Nilai rata-rata dan persentase ketuntasan belajar yang rendah menunjukkan bahwa tujuan pem-belajaran belum tercapai. Hasil inilah yang mendasari pelaksanaan penelitian tindakan kelas ini. Penggunaan model pembelajaran kooperatif tipe kepala bernomor (Numbered Heads Together) diharapkan dapat meningkatkan hasil belajar siswa.

Nilai rata-rata hasil belajar siswa $=\frac{\sum \text { Nilai Siswa }}{\text { Jumlah siswa }} \times 100$

Selain itu, penelitian ini juga

menghitung persentase ketuntasan Tabel 1 Hasil tes penjajakan

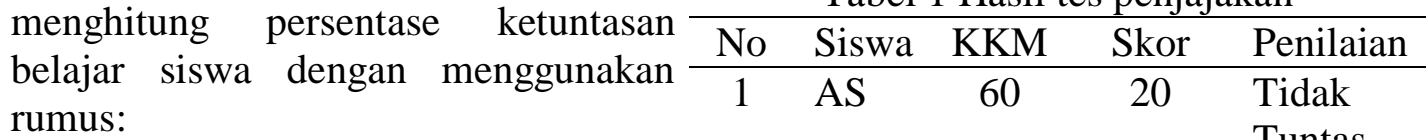

ketuntasan belajar siswa $(\%)=\frac{\sum \text { Siswa yang tuntas }}{\text { Jumlah siswa }} \times 100$

2 AP

60

Tuntas

Tuntas 


\begin{tabular}{|c|c|c|c|c|}
\hline 3 & AY & 60 & 60 & Tuntas \\
\hline 4 & DT & 60 & 50 & $\begin{array}{l}\text { Tidak } \\
\text { Tuntas }\end{array}$ \\
\hline 5 & HB & 60 & 50 & $\begin{array}{l}\text { Tidak } \\
\text { Tuntas }\end{array}$ \\
\hline 6 & MI & 60 & 30 & $\begin{array}{l}\text { Tidak } \\
\text { Tuntas }\end{array}$ \\
\hline 7 & TA & 60 & 60 & Tuntas \\
\hline 8 & $\mathrm{OM}$ & 60 & 30 & $\begin{array}{l}\text { Tidak } \\
\text { Tuntas }\end{array}$ \\
\hline 9 & YP & 60 & 60 & Tuntas \\
\hline \multicolumn{3}{|c|}{ Jumlah } & 420 & \\
\hline \multicolumn{3}{|c|}{ Nilai Rata-Rata } & 46,67 & \\
\hline \multicolumn{3}{|c|}{ Ketuntasan Belajar } & $44,44 \%$ & \\
\hline
\end{tabular}

\section{Hasil Penelitian pada Siklus I}

Kegiatan penelitian pada siklus I dilaksanakan pada hari Selasa, 11 Januari 2017 (Pertemuan ke-1 Siklus I), hari Selasa, 18 Januari 2017 (Pertemuan ke-2 Siklus II), dan hari Selasa, 25 Januari 2017 (Evaluasi Hasil Belajar Siklus I). Kegiatan penelitian pada siklus I terdiri atas perencanaan, pelaksanaan, pengamatan, dan refleksi.

\section{Perencanaan}

atas:

Kegiatan perencanaan terdiri

a. Menyusun Rencana Pelaksanaan Pembelajaran/RPP

b. Menetapkan materi bahan ajar

c. Merancang skenario pembelajaran

d. Menyiapkan media pembelajaran

e. Menyusun alat evaluasi hasil belajar

\section{Pelaksanaan}

Penelitian tindakan kelas dilakukan pada pembelajaran pendidikan Kewarganegaraan khususnya pada materi Kerjasama Negara-Negara Asia Tenggara. Materi yang disampaikan dalam siklus I adalah materi tentang ASEAN dan Deklarasi Bangkok (pertemuan ke-1 Siklus I) dan materi tentang Latar Belakang Kerjasama, Struktur, dan Keanggotaan ASEAN (pertemuan ke-2 Siklus I). Kegiatan dilaksanakan dalam tiga tahap yaitu kegiatan awal, kegiatan inti, dan kegiatan akhir.

1. Kegiatan Awal, terdiri atas:

a. Guru mengucapkan salam dan membuka pelajaran dengan menyapa dan menanyakan kabar siswa.

b. Guru menunjuk salah satu siswa untuk memimpin doa

c. Guru memeriksa kehadiran siswa

d. Guru memberikan apersepsi

e. Guru menyampaikan tujuan pembelajaran yang akan dicapai.

f. Guru meminta siswa untuk membentuk kelompok kecil dan setiap siswa dalam kelompok mendapatkan nomor

2. Kegiatan Inti, terdiri atas:

a. Guru menyampaikan materi pelajaran

b. Guru memberikan tugas kepada siswa untuk dikerjakan secara berkelompok

c. Setiap kelompok mendiskusikan jawaban yang benar dan memastikan tiap anggota kelompok dapat mengerjakan/mengetahui jawabannya

d. Guru memanggil salah satu nomor peserta didik dan peserta didik yang nomornya dipanggil melaporkan hasil diskusi kelompoknya.

e. Guru memberikan kesempatan kepada siswa dari kelompok lain untuk menanggapi hasil diskusi kelompok penyaji. Setelah itu, guru menunjuk nomor yang lain.

3. Kegiatan Akhir, terdiri atas:

a. Guru memberi kesempatan kepada beberapa siswa untuk menyampaikan pendapatnya tentang pembelajaran yang telah diikuti.

b. Guru membantu siswa untuk mereview kegiatan pembelajaran

c. Guru memberikan tugas 

d. Guru memberi gambaran pembelajaran berikutnya.
e. Guru menyampaikan pesan moral.
f. Guru melaksanakan evaluasi siklus I

\section{Pengamatan}

Selama kegiatan pembelajaran berlangsung, ada beberapa catatan penting yang perlu diperhatian berkaitan dengan proses pembelajaran. Hasil pengamatan siswa pada Siklus I disajikan pada Tabel 2. Secara umum, hasil pengamatan sebagai berikut:

a. Kegiatan pembelajaran berjalan dengan lancar.

b. Siswa mendengarkan penjelasan guru secara aktif

c. Kegiatan pembelajaran masih berpusat pada guru

d. Sebagian siswa belum berani menyampaikan hasil diskusi di depan kelas dan juga belum berani untuk memberikan tanggapan mengenai presentasi hasil diskusi kelompok lain.

Hasil pengamatan yang disajikan pada Tabel 2 menunjukkan bahwa seluruh siswa mendengarkan penjelasan guru dengan aktif dan membentuk kelompok yang heterogen. Delapan dari Sembilan siswa juga bersedia untuk mendiskusikan jawaban dengan teman sekelompok. Akan tetapi, tidak semua siswa berani untuk menyampaikan hasil diskusi kelompoknya dan memberikan tanggapan terhadap presentasi kelompok lain. Oleh karenanya, guru diharapkan mampu untuk memberikan motivasi kepada siswa sebagai upaya untuk meningkatkan kepercayaan diri siswa sehingga siswa memiliki keberanian untuk menyampaikan hasil diskusi dan juga memberikan tanggapan.

Tabel 2 Hasil pengamatan aktivitas siswa pada akhir Siklus I

\begin{tabular}{clcc}
\hline No & \multicolumn{1}{c}{ Kriteria } & n & $\%$ \\
\hline 1 & $\begin{array}{l}\text { Siswa mendengarkan penjelasan guru } \\
\text { dengan aktif }\end{array}$ & 9 & $\begin{array}{c}100,00 \\
\%\end{array}$ \\
2 & $\begin{array}{l}\text { Siswa membentuk kelompok yang } \\
\text { heterogen }\end{array}$ & 9 & $\begin{array}{c}100,00 \\
\%\end{array}$ \\
3 & $\begin{array}{l}\text { Siswa bersedia untuk mendiskusikan } \\
\text { jawaban dengan teman sekelompok }\end{array}$ & 8 & $88,89 \%$ \\
4 & Siswa berani menyampaikan hasil diskusi & 6 & $66,67 \%$ \\
5 & $\begin{array}{l}\text { Siswa berani menyampaikan tanggapan } \\
\text { engenai presentasi hasil diskusi kelompok } \\
\text { lain }\end{array}$ & 6 & $66,67 \%$ \\
& & \\
\hline
\end{tabular}

Keterangan:

n: jumlah, \%: persentase

Selain evaluasi proses Peningkatan nilai rata-rata kelas sekitar pembelajaran, penelitian ini juga 20,55 point. Peningkatan hasil juga melakukan evaluasi hasil belajar terjadi pada presentase ketuntasan melalui tes. Hasil evaluasi hasil belajar belajar siswa. Ketuntasan belajar siswa siswa pada Siklus I disajikan pada pada akhir siklus I adalah 77,78\%. Tabel 3. Nilai rata-rata kelas yang Ketuntasan belajar siswa pada akhir diperoleh di akhir siklus I adalah 67,22. siklus I juga meningkat dibandingkan Nilai ini lebih besar dibandingkan dengan ketuntasan belajar siswa saat dengan nilai rata-rata kelas saat tes tes penjajakan (pratindakan) yaitu penjajakan (pratindakan) yaitu 46,67. sebesar 44,44\%. Peningkatan yang 
terjadi sebesar 33,34\%. Berdasarkan hasil tersebut, dapat disimpulkan bahwa penggunaan model pembelajaran tipe kepala bernomor dalam pembelajaran dapat meningkatkan hasil belajar siswa pada mata pelajaran PKn.

Tabel 3 Hasil penelitian pada Siklus I

\begin{tabular}{ccccc}
\hline No & Siswa & KKM & Skor & Penilaian \\
\hline 1 & AS & 60 & 45 & $\begin{array}{c}\text { Tidak } \\
\text { Tuntas }\end{array}$ \\
2 & AP & 60 & 80 & Tuntas \\
3 & AY & 60 & 95 & Tuntas \\
4 & DT & 60 & 70 & Tuntas \\
5 & HB & 60 & 60 & Tuntas \\
6 & MI & 60 & 50 & Tidak \\
& & & & Tuntas \\
7 & TA & 60 & 60 & Tuntas \\
8 & OM & 60 & 70 & Tuntas \\
9 & YP & 60 & 75 & Tuntas \\
Jumlah & & 605 & \\
Nilai Rata-Rata & 67,22 & \\
Ketuntasan Belajar & $77,78 \%$ & \\
\hline
\end{tabular}

\section{Refleksi}

Refleksi dari hasil penelitian adalah sebagai berikut:

1. Melaksanakan

kegiatan pembelajaran yang melibatkan keaktifan seluruh siswa.

2. Mendampingi siswa dalam bekerja secara berkelompok

3. Mengevaluasi pekerjaan siswa

4. Memotivasi siswa agar berani menyampaikan hasil pekerjaannya depan kelas.

5. Mendampingi siswa dalam menuliskan laporan

6. Merumuskan tindakan siklus II berdasarkan temuan pada siklus I.

\section{Hasil Penelitian pada Siklus II}

Kegiatan penelitian pada siklus II dilaksanakan pada hari Selasa, 8 Februari 2017 (Pertemuan ke-1 Siklus II), hari Selasa, 15 Februari 2017
(Pertemuan ke-2 Siklus II), dan hari Selasa, 22 Februari 2017 (Evaluasi Hasil Belajar Siklus II). Kegiatan penelitian pada siklus II terdiri atas perencanaan, pelaksanaan, pengamatan, dan refleksi.

\section{Perencanaan} atas:

Kegiatan perencanaan terdiri

a. Menyusun Rencana Pelaksanaan Pembelajaran/RPP

b. Menetapkan materi bahan ajar

c. Merancang skenario pembelajaran

d. Menyiapkan media pembelajaran

e. Menyusun alat evaluasi hasil belajar

\section{Pelaksanaan}

Penelitian tindakan kelas dilakukan pada pembelajaran pendidikan Kewarganegaraan khususnya pada materi Kerjasama Negara-Negara Asia Tenggara. Materi yang disampaikan dalam siklus II adalah materi tentang Kerjasama ASEAN (pertemuan ke-1 Siklus II) dan materi tentang prinsip dan logo ASEAN (pertemuan ke-2 Siklus II). Kegiatan dilaksanakan dalam tiga tahap yaitu kegiatan awal, kegiatan inti, dan kegiatan akhir.

1. Kegiatan Awal, terdiri atas:

a. Guru mengucapkan salam dan membuka pelajaran dengan menyapa dan menanyakan kabar siswa.

b. Guru menunjuk salah satu siswa untuk memimpin doa

c. Guru memeriksa kehadiran siswa

d. Guru memberikan apersepsi

e. Guru menyampaikan tujuan pembelajaran yang akan dicapai.

f. Guru meminta siswa untuk membentuk kelompok kecil dan setiap siswa dalam kelompok mendapatkan nomor 
2. Kegiatan Inti, terdiri atas:

a. Guru menyampaikan materi pelajaran

b. Guru memberikan tugas kepada siswa untuk dikerjakan secara berkelompok

c. Setiap kelompok mendiskusikan jawaban yang benar dan memastikan tiap anggota kelompok dapat mengerjakan/mengetahui jawabannya

d. Guru memanggil salah satu nomor peserta didik dan peserta didik yang nomornya dipanggil melaporkan hasil diskusi kelompoknya.

e. Guru memberikan kesempatan kepada siswa dari kelompok lain untuk menanggapi hasil diskusi kelompok penyaji. Setelah itu, guru menunjuk nomor yang lain.

3. Kegiatan Akhir, terdiri atas:

a. Guru memberi kesempatan kepada beberapa siswa untuk menyampaikan pendapatnya

Tabel 4 Hasil pengamatan aktivitas siswa pada akhir Siklus II

\begin{tabular}{clcc}
\hline No & \multicolumn{1}{c}{ Kriteria } & n & $\%$ \\
\hline 1 & Siswa mendengarkan penjelasan guru dengan & 9 & $100,00 \%$ \\
& aktif & & \\
2 & Siswa membentuk kelompok yang heterogen & 9 & $100,00 \%$ \\
3 & $\begin{array}{l}\text { Siswa bersedia untuk mendiskusikan jawaban } \\
\text { dengan teman sekelompok }\end{array}$ & 9 & $100,00 \%$ \\
4 & Siswa berani menyampaikan hasil diskusi & 8 & $88,89 \%$ \\
5 & Siswa berani menyampaikan tanggapan & 8 & $88,89 \%$ \\
& engenai presentasi hasil diskusi kelompok lain & & \\
\hline
\end{tabular}

Keterangan:

$\mathrm{n}$ : jumlah, \%: persentase

Hasil pengamatan yang disajikan pada Tabel 4 menunjukkan bahwa seluruh siswa mendengarkan penjelasan guru dengan aktif, membentuk kelompok yang heterogen, dan bersedia untuk mendiskusikan jawaban dengan teman sekelompok. Keberanian siswa untuk menyajikan hasil diskusi dan juga memberikan tanggapan juga meningkat walaupun masih ada satu orang siswa yang belum tentang pembelajaran yang telah diikuti.

b. Guru membantu siswa untuk mereview pembelajaran

kegiatan

c. Guru memberikan tugas

d. Guru memberi gambaran pembelajaran berikutnya.

e. Guru menyampaikan pesan moral.

f. Guru melaksanakan evaluasi siklus II

\section{Pengamatan}

Kegiatan pembelajaran pada siklus II sudah mulai menampakkan kemajuan yang berarti, hal ini disebabkan oleh siswa sudah mulai terbiasa dengan cara pembelajaran yang baru yang diterapkan oleh guru. Guru sudah dapat memotivasi siswa untuk berani menyampaikan pertanyaan dan jawaban dengan memberikan berbagai penguatan. Hasil pengamatan untuk siklus II disajikan pada Tabel 4. 
siswa pada Siklus II disajikan pada Tabel 5.

Tabel 5 Hasil penelitian pada Siklus II

\begin{tabular}{|c|c|c|c|c|}
\hline No & Siswa & KKM & Skor & Penilaian \\
\hline 1 & $\mathrm{AS}$ & 60 & 50 & $\begin{array}{c}\text { Tidak } \\
\text { Tuntas }\end{array}$ \\
\hline 2 & AP & 60 & 100 & Tuntas \\
\hline 3 & AY & 60 & 90 & Tuntas \\
\hline 4 & DT & 60 & 80 & Tuntas \\
\hline 5 & HB & 60 & 70 & Tuntas \\
\hline 6 & MI & 60 & 60 & Tuntas \\
\hline 7 & TA & 60 & 70 & Tuntas \\
\hline 8 & $\mathrm{OM}$ & 60 & 65 & Tuntas \\
\hline 9 & YP & 60 & 80 & Tuntas \\
\hline \multicolumn{3}{|c|}{ Jumlah } & 665 & \\
\hline \multicolumn{3}{|c|}{ Nilai Rata-Rata } & 73,89 & \\
\hline \multicolumn{3}{|c|}{ Ketuntasan Belajar } & $88,89 \%$ & \\
\hline
\end{tabular}

Tabel 5 memperlihatkan bahwa nilai rata-rata kelas yang diperoleh di akhir siklus II adalah 73,89. Nilai ini lebih besar dibandingkan dengan nilai rata-rata kelas pada akhir Siklus I yaitu 67,22 . Peningkatan nilai rata-rata kelas sekitar 6,67 point. Peningkatan hasil juga terjadi pada presentase ketuntasan belajar siswa. Ketuntasan belajar siswa pada akhir siklus II adalah 88,89\%. Ketuntasan belajar siswa pada akhir siklus II juga meningkat dibandingkan dengan ketuntasan belajar siswa pada akhir siklus I sebesar 77,78\%. Peningkatan yang terjadi sebesar $11,11 \%$. Berdasarkan hasil tersebut, dapat disimpulkan bahwa penggunaan model pembelajaran tipe kepala bernomor dalam pembelajaran dapat meningkatkan hasil belajar siswa pada mata pelajaran Pendidikan Kewarganegaraan.

\section{Refleksi}

Mengingat tindakan siklus II telah mengalami kemajuan yang cukup signifikan, baik berdasarkan aktivitas siswa maupun berdasarkan hasil belajar maka peneliti memutuskan untuk menghentikan tindakan pada siklus II.
Dengan demikian, penelitian tindakan kelas dianggap selesai.

\section{Analisis Peningkatan Hasil Belajar} Siswa

Hasil belajar siswa dilihat dari nilai rata-rata kelas dan ketuntasan belajar siswa. Hasil penelitian memperlihatkan bahwa nilai rata-rata kelas yang pada saat pratindakan hanya sebesar 46,67 meningkat menjadi 67,22 pada akhir siklus I dan kembali meningkat menjadi 73,89 pada akhir siklus II. Apabila hasil pada akhir siklus II dibandingkan dengan hasil pada saat pratindakan maka diperoleh selisih sebesar 27,22 point. Selain peningkatan nilai rata-rata kelas, ketuntasan belajar siswa juga meningkat. Ketuntasan belajar siswa pada saat pratindakan hanya sebesar $44,44 \%$ meningkat menjadi $77,78 \%$ pada akhir siklus I dan kembali meningkat menjadi 88,89\% pada akhir siklus II (Gambar 1). Apabila hasil pada akhir siklus II dibandingkan dengan hasil pada saat pratindakan maka diperoleh selisih sebesar 44,45 point.

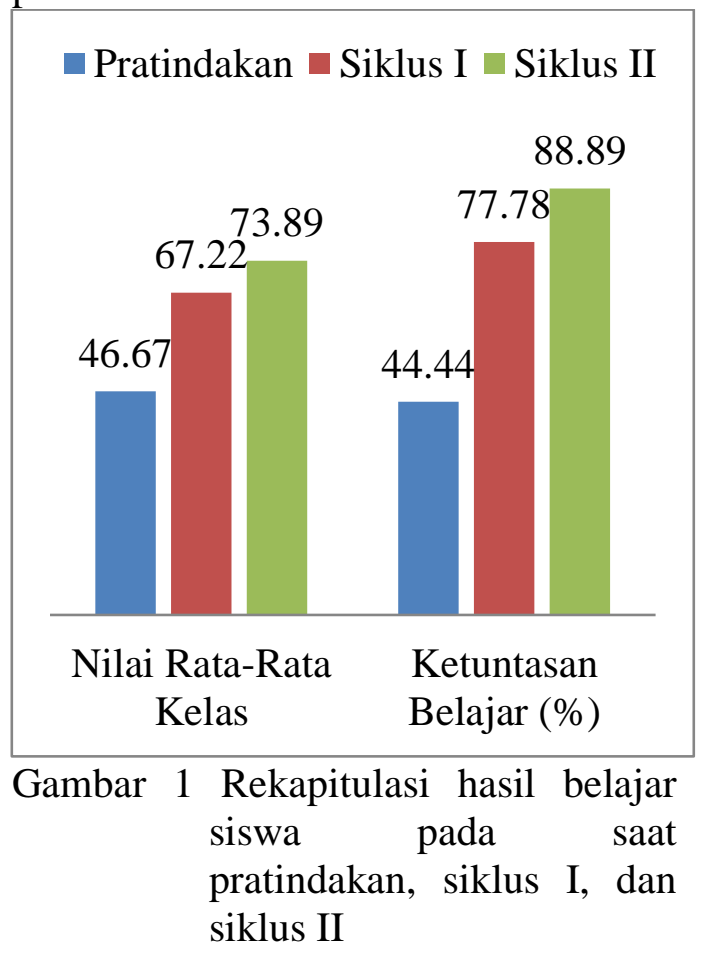


Hasil penelitian menunjukkan bahwa terjadi peningkatan hasil belajar siswa dari sebelum dilaksanakan tindakan sampai dengan setelah dilaksanakan tindakan (siklus I dan siklus II). Berdasarkan hasil penelitian, dapat disimpulkan bahwa penggunaan model pembelajaran kooperatif tipe kepala bernomor (Numbered Heads Together) dapat meningkatkan hasil belajar siswa dalam pembelajaran Pendidikan Kewarganegaraan. Hasil penelitian ini mendukung hasil penelitian sebelumnya yang menyebutkan bahwa penggunaan model pembelajaran kooperatif tipe kepala bernomor (Numbered Heads Together) dapat meningkatkan hasil belajar siswa dalam pembelajaran Pendidikan Kewarganegaraan (Afandi, 2012; Yasni, 2015; Zukira, Harun, dan Jamaludin, 2015; Irmayani, 2016; dan Suwastana, 2016).

\section{SIMPULAN}

Model pembelajaran kooperatif tipe kepala bernomor (Numbered Heads Together) dapat meningkatkan hasil belajar siswa kelas VI Semester Genap tahun pelajaran 2016/2017 SDN. No. 013/XI Sumur Anyir dalam mata pelajaran Pendidikan Kewarganegaraan. Hasil ini dibuktikan dengan adanya peningkatan hasil belajar siswa yang dilihat dari peningkatan nilai rata-rata kelas dan ketuntasan belajar sebelum dilakukan tindakan dan setelah dilaksanakan tindakan (siklus I dan siklus II). Selain hasil belajar, siswa juga mengalami peningkatan juga dalam hal aktivitas siswa. Hasil pengamatan menunjukkan bahwa seluruh siswa telah mendengarkan penjelasan guru dengan aktif, membentuk kelompok yang heterogen, dan bersedia untuk mendiskusikan jawaban dengan teman sekelompok. Sebagian besar siswa juga telah berani untuk menyampaikan hasil diskusi kelompoknya dan memberikan tanggapan terhadap presentasi kelompok lain.

\section{Saran}

Berdasarkan temuan penelitian, pendidik diharapkan dapat:

1. Menggunakan model pembelajaran kooperatif tipe kepala bernomor (Numbered Heads Together) untuk meningkatkan hasil belajar siswa dalam mata pelajaran Pendidikan Kewarganegaraan,

2. Mengenali siswa dengan baik untuk memudahkan pendidik menemukan model, pendekatan, strategi, metode, dan teknik pembelajaran yang tepat,

3. Menggunakan model, pendekatan, strategi, metode, dan teknik pembelajaran yang variatif dan inovatif, dan

4. Penelitian yang selanjutnya diharapkan dapat melakukan perbaikan agar diperoleh hasil yang lebih baik

\section{DAFTAR PUSTAKA}

Afandi, M. (2012). Peningkatan minat dan prestasi belajar PKn materi mengenal lembaga sistem pemerintahan melalui pembelajaran kooperatif tipe Numbered Heads Together (NHT) di kelas IV SD Negeri Panimbang 05. Diambil dari: http://research.unissula.ac.id/file/ publikasi/211313015/9256 jurnal_2012_ok.pdf.

Irmayani. (2016). Meningkatkan Prestasi Belajar Pkn Menggunakan Model Pembelajaran Numbered Heads Together pada Siswa Kelas V SD Inpres Palupi. Jurnal Kreatif Tadulako Online. Vol. 4 No. 4.
Kaelan. (2016). Pendidikan
Kewarganegaraan untuk
Perguruan Tinggi. Yogyakarta: Paradigma 
Suprihatiningrum, J. (2014). Strategi

Pembelajaran: Teori dan

Aplikasi. Yogyakarta: Ar Ruzz

Media

Suwastana, I. W. (2016). Penerapan

Pembelajaran Melalui Model

Kooperatif Numbered Heads

Together Siswa Kelas V SDN No

1 Tonggolobibi Untuk

Meningkatkan Prestasi Belajar

PKn. Jurnal Kreatif Tadulako

Online. Vol. 4 No. 1.

Yasni. (2015). Peningkatan Hasil

Belajar PKn Melalui Model

Pembelajaran Kooperatif Kepala

Bernomor Terstruktur Pada

Siswa Kelas V SD Negeri 005

Kebun Lado Kecamatan Singingi

Kabupaten Kuantan Singingi.

Jurnal PPKn \& Hukum. Vol. 10

No. 1.

Zukira, Harun, A. H., \& Jamaludin. (2015). Meningkatkan Hasil Belajar Siswa Kelas III Sekolah Dasar Alkhairaat Towera Melalui Model Pembelajaran Kooperatif Tipe Number Heads Together (NHT) pada Mata Pelajaran PKn. Jurnal Kreatif Tadulako Online. Vol. 3 No. 4. 